WHAT DO I TAKE WITH ME?: THE MEDIATING EFFECT OF SPIN-OUT TEAM SIZE AND TENURE ON THE FOUNDER-FIRM PERFORMANCE RELATIONSHIP

by

\author{
Rajshree Agarwal ${ }^{\mathrm{i}}$ \\ University of Maryland
}

Benjamin A. Campbell

The Ohio State University

\author{
April M. Franco \\ University of Toronto Scarborough
}

Martin Ganco

University Of Minnesota

CES 13-17

April, 2013

The research program of the Center for Economic Studies (CES) produces a wide range of economic analyses to improve the statistical programs of the U.S. Census Bureau. Many of these analyses take the form of CES research papers. The papers have not undergone the review accorded Census Bureau publications and no endorsement should be inferred. Any opinions and conclusions expressed herein are those of the author(s) and do not necessarily represent the views of the U.S. Census Bureau. All results have been reviewed to ensure that no confidential information is disclosed. Republication in whole or part must be cleared with the authors.

To obtain information about the series, see www.census.gov/ces or contact Fariha Kamal, Editor, Discussion Papers, U.S. Census Bureau, Center for Economic Studies 2K132B, 4600 Silver Hill Road, Washington, DC 20233, CES.Papers.List@census.gov. 


\begin{abstract}
Our study examines the mediating effect of spin-out team characteristics on the relationship between founder quality and parent and spin-out performance. Since the ability to transfer or recreate complementary assets is a critical determinant of performance, we theorize and show that founders with greater ability impact both parent firm and spin-out performance by assembling teams that represent strong complementary human capital. Using linked employeeemployer US Census data from the legal services industry, we find founding team size and tenure mediate the founder quality effect. Our findings have practical implications for both managers of existing firms and aspiring founders as it relates to their human resource strategies: the factor most salient to performance is not the individual quality per se, but the manner in which it impacts the transfer and spillover of complementary human capital.
\end{abstract}

Corresponding author. All authors contributed equally and the names are listed in alphabetical order. We thank the Ewing Marion Kauffman Foundation for support of the project. The research in this paper was conducted under Special Sworn Status of the U.S. Census Bureau at the Chicago Census Research Data Center. Any opinions and conclusions expressed herein are those of the authors and do not necessarily represent the views of the U.S. Census Bureau. All results have been reviewed to ensure that no confidential information is disclosed. This research uses data from the Census Bureau's Longitudinal Employer Household Dynamics Program, which was partially supported by the following National Science Foundation Grants: SES-9978093, SES-0339191 and ITR-0427889; National Institute on Aging Grant AG018854; and grants from the Alfred P. Sloan Foundation. The authors are grateful to Seth Carnahan for able research assistance. The manuscript has benefited from comments received from Gilad Chen, and seminar participants at the 2011 Academy of Management meetings, HBS Strategy Research Conference, University of Illinois, University of Maryland and University of Toronto. 


\title{
What Do I TaKe With Me?: The Mediating EfFect of Spin-out Team Size and Tenure on the Founder-Firm Performance Relationship
}

\author{
"Not aeyonecan bea founder. Wetalk abat thefandess of startups and companies Wefous on the \\ foundes Thefaundes get press coverage Samtimes theygt rich But for eley faunder, thereis an early employee \\ that takes near equal nisksinjainingan eadty-stagecompany." ～D avid Crow, StartupNorth (2009)
}

Extant work on spin-outs - start-ups founded by a former employee of an established firm within the same industry - underscores the role of founders as conduits of knowledge from the parent firm to the new venture (Agarwal, Echambadi, Franco, \& Sarkar, 2004; Franco \& Filson, 2006; Klepper \& Sleeper, 2005; Phillips, 2002). Moreover, work on entrepreneurship has focused on understanding which employees are most likely to leave and start entrepreneurial ventures; both Klepper and Thompson (2010) and Campbell, G anco, Franco and Agarwal (2012) theorize why the best employees are the most likely to spin out. Not surprisingly, founder characteristics are also critical for firm performance: the departure of higher quality founders create greater adverse effects for the parent firm, and higher beneficial effects for the spin-out firm (Campbell et al., 2012; Klepper \& Thompson, 2010; Phillips, 2002).

The scholarly attention on founder characteristics is mirrored by the attention they receive in the popular press. However, founders rarely venture out on their own (Wasserman, 2012), often turning to their colleagues to assemble a team (Wezel, Cattani, \& Pennings, 2006; Groysberg, Nanda \& Prats, 2009). For example, when Johnson and Johnson spun out in 1886 from Seabury and Johnson, all three members of the founding team and many of its first 14 employees came from the parent firm (Kilmer House, 2012). Walt D isney recruited Mickey Mouse co-creator Ub Iwerks, a fellow employee at Pesman-Rubin Commercial Art Studio, when founding D isney (G abler, 2006). Similar accounts abound in the semiconductor industry, as exemplified by Gordon Moore and Robert Noyce hiring away Andrew G rove when leaving Fairchild Semiconductor to found Intel (Moore and D avis, 2004). Consistent with these anecdotes, scholars have found that the size and tenure of the founding and early employee 
teams adversely impacts parent performance (Wezel et al., 2006) and positively impacts spin-out performance (Phillips, 2002; Beckman, 2006; D elmar and Shane, 2006).

However, the theoretical models underpinning studies that examine the "main effects" of either founder quality or founding team size and tenure on parent/ spin-out performance may not fully capture the relationships between these constructs. Specifically, these models of performance do not explicitly acknowledge the interplay between founder quality and the size and experience of the founding team. For example, while Campbell et al. (2012) discuss the founder's ability to transfer and recreate complementary assets as a key factor in determining the effect on source firm performance, they do not separate the impact of founder quality from the complementary human assets that founders takewiththemfrom the parent to the spin-out firm. On the other hand, models that focus only on founding team size and tenure (e.g. Wezel et al., 2006; Phillips, 2002) fail to acknowledge that these are related to the founder's ability to convince their colleagues to depart with them in undertaking a risky new venture. As the anecdotal evidence above suggests, founders such as the Johnson brothers, Walt D isney, and Gordon Moore were high quality individuals. However, their new ventures survived and thrived to become icons of modem industry not only due to their own ability, but also due to the abilities and synergies of the team that they were able to transfer across the firms.

Accordingly, we develop and test our theory of the mediating effect of team size and tenure on the effect of founder quality and parent firm and spin-out performance. We argue that founder quality determines the size and tenure of spin-out teams that they can assimilate from their prior employer, which in turn impacts firm performance. Specifically, we hypothesize that size and tenure of spin-out team members mediate the negative relationship between founder quality and parent performance, and the positive relationship between founder quality and spin-out performance.

These relationships are particularly relevant to professional service firms. In professional service firms, knowledge resides in human assets and complementary organizational routines and procedures are critical for the creation and appropriation of value. Further, most of the existing 
literature on the effect of founder quality on parent and spin-out performance has focused on professional service firms (e.g. Campbell et al., 2012; Phillips, 2002; Wezel et al., 2006;

Groysberg et al., 2009). In line with this established literature, we examine our hypotheses in the empirical setting of the legal services industry. Using a custom data extract of the Longitudinal Employer-Household D ynamics (LEHD) Project at the U.S. Census Research D ata Center, we find that founder earnings, which we argue serves as a strong proxy for the multiple relevant dimensions of founder quality in this context, is an important determinant of both team size and tenure. We also find strong support for our hypotheses that team size and tenure mediate the effect of founder quality on spin-out performance. On the parent side, the size of the spin-out team mediates the adverse effect of founder quality on parent firm performance while there is no indirect effect attributable to the tenure of the founding team that a founder assembles.

O ur study contributes to the entrepreneurship and strategic human capital literatures. In the entrepreneurship domain, we provide an important complement to prior work (Phillips, 2002; Wezel et al., 2006; Aime et al., 2010; Campbell et al., 2012) by developing and testing a holistic model of how founders and their spin-out teams jointly determine start-up performance. Contributing to the employee entrepreneurship literature (Agarwal et al., 2004; Klepper \& Sleeper, 2005; Klepper \& Thompson, 2010), our results indicate that the founders' prior experience may help them to create large start-up teams with shared relevant prior work experience, which then subsequently improves performance. At a higher level, our analysis implies that to understand the micro-foundations of entrepreneurship, researchers should shift their attention to theories and empirical methods that go beyond focusing on one variable at a time and develop richer models that allow for interrelationships between variables and levels of analysis. In the context of strategic human capital, we demonstrate how founder quality affects the founder's ability to assemble an effective team of former co-workers. We find that this interaction is critical for understanding the rich relationship between human capital and performance within organizations; it highlights that the impact on value of an individual is manifested through the team that is compiled, rather than through the effects of individuals 
alone. Thus, this provides researchers with an important step towards unpacking the mechanism through which mobile human capital affects performance of the firms that receive or lose human capital.

O ur findings have multiple practical implications. The popular press frequently emphasizes founders as the crucial determinant of performance of their firms. Similarly, the loss of key employees is considered a significant threat to the competitiveness of established firms. O ur results indicate that the role of entire teams that share prior work experience and move to a new setting may be underappreciated. From the perspective of established firms, our findings imply that high quality employees attract not only a greater number of employees, but particularly those employees who have more experience. The negative performance impact on the established firm is then exacerbated by the loss of employees with complementary skills rather than driven purely by a loss of a high quality individual. These implications may lead to distinct employee retention strategies. For instance, managers may want to target their retention strategies toward the co-workers and subordinates of the employee who is likely to spin out. Such strategies will help minimize the negative impact associated with the loss of human capital as well the competitive threat from the start-up. These strategies are also easier to implement as they allow managers to be reactive and respond to actual threats of employee spin-outs as opposed to a proactive approach that must forecast which employees are likely to leave to found a start-up. From the perspective of the spin-out, our results highlight the importance of the founder's human capital in the entrepreneurial team assembly process. Importantly, our study shows that holding high human capital and high rank within an established firm is correlated with the ability to attract complementary human capital and thus enhance the success of future entrepreneurs.

\section{THEORETICAL FRAMEWORK}

\section{Brief Literature Review}

Extant research points to the beneficial effect of founder's previous work experience at the parent firm on spin-out performance (Agarwal et al., 2004; Franco \& Filson, 2006; Klepper 
\& Sleeper, 2005; Phillips, 2002) and adverse effect of losing experienced employees to spin-outs on the performance of the parent firm (Phillips, 2002; Wezel et al., 2006; Aime et al., 2010; Campbell et al., 2012). The positive performance consequences for spin-outs have been attributed to the role of founders' knowledge as a conduit for the inheritance of technological and market pioneering capabilities (Agarwal et al., 2004) and managerial and process capabilities (D encker, G ruber, \& Shah, 2009), or to other relevant knowledge such as embeddedness within social networks (Burton, Sørensen, \& Beckman, 2002). Many of these studies, however, focus on aggregate firm-level capability measures, rather than use measures of individual characteristics of the founder. Among studies that explicitly link founder characteristics to the performance of either the parent or the spin-out, scholars have focused on the "core" founder's ability (Wasserman, 2012), where the core founder is the individual who has the highest prior rank (Phillips, 2002; Rajan and Zingales, 2001; Wezel et al., 2006), highest prior earnings (Campbell et al., 2012), or is otherwise a "star" performer (G roysberg, Lee and Nanda, 2008; G roysberg, et al., 2009). Regardless of the measure used, these studies consistently find that founder quality negatively impacts parent firm performance, and positively impacts spin-out firm performance.

Acknowledging the fact that individuals rarely venture out on their own, scholars have also examined the characteristics of the team of employees that leave a parent firm to join a start-up (Beckman, 2006; Eisenhardt \& Schoonhoven, 1990; Groysberg et al., 2009; Wezel et al., 2006). This research has focused on two important characteristics of the spin-out team: team size and team tenure. We turn to each below, noting that team size represents the transfer of resources from the parent to the spin-out firm, while team tenure is associated with shared experiences that enable the replication of the routines and procedures from the parent firm to the spin-out.

The size of an exiting team represents a transfer of complementary resources due to both a simple additive effect of the capabilities of each individual team member and synergies or complementarities of capabilities within the set of team members. Larger team sizes imply greater transfer of aggregate capabilities from the parent to the spin-out (Wuchty, Jones, \& Uzzi, 
2007) and reflect the complementary fit among the individuals. Indeed, both Agarwal et al. (2004) and Wezel et al. (2006) note that larger teams include complementary capabilities such as technical and market knowledge. In the context of parent firm performance, Wezel et al. (2006) and Phillips (2002) show that team exits relative to individual exit imply greater disruptions and hence translate into a greater negative impact on the parent firm. Additionally, when parents and spin-outs compete in the same markets, the increased competition caused by the spin-out (Phillips, 2002) results in an additional mechanism through which the transfer of rival resources represented by team size adversely affects parent firm performance. For spin-outs, larger teams represent greater resource endowments and greater perceived legitimacy and reputation, and thus provide performance benefits (Beckman, 2006; D elmar \& Shane, 2006; Phillips, 2002). Also, larger teams facilitate specialization of the team members, which enables each individual to concentrate on specific roles based on their specific skills (Sine, Mitsuhashi, \& Kirsch, 2006).

Additionally, team tenure has been highlighted by several scholars as critical to the replication of routines that were present in the parent firm within the spin-out firm context (Beckman, 2006; Eisenhardt \& Schoonhoven, 1990; Phillips, 2002; Wezel et al., 2006). Harking back to Stinchcombe (1965), these scholars have stressed that spin-outs' ability to replicate organizational routines from their parent firm depends on the level of team tenure, particularly when these routines are embodied in shared knowledge. Because routines reflect existing interaction patterns among multiple actors and codification of knowledge (Nelson \& Winter, 1982), experiential wisdom (G avetti \& Levinthal, 2000), greater trust and communication (Eisenhardt and Schoonhoven, 1990) and are associated with learning-by-doing (Argote, Beckman, \& Epple, 1990; Becker, 2005), teams with more experience or tenure at the parent firm are better able to recreate structural and strategic routines from their parents (Beckman, 2006; Eisenhardt and Schoonhoven, 1990; Sine et al., 2006; Wezel et al. 2006). Accordingly, scholars have found a negative effect of the tenure of departing teams on parent firm performance. Wezel et al. (2006) and Phillips (2002) argue that the tenure of employee teams leaving the organization for spin-outs is associated with a disruption of routines, thus driving the 
adverse performance effect on the parent. Importantly, Aime et al. (2010) find that the loss of competitive advantage can occur even if the parent firms are able to retain established routines. For spin-outs, the positive effect of team tenure on performance has been attributed to a superior ability to replicate routines, norms and procedures, given greater managerial skills and tacit knowledge regarding setting up and running an organization (Mostafa \& Klepper, 2010; Phillips, 2002; Sine et al., 2006; Wezel et al., 2006) that result in quicker decision making and thus time to market (Beckman, 2006; Eisenhardt \& Schoonhoven, 1990).

Thus, in summary, the existing literature has substantially improved our understanding of the competitive dynamics between parent and spin-out performance as it relates to founder quality, departing team size, and departing team tenure. However, these studies make an important implicit assumption: that departing team size and team tenure are determined independently of founder quality, and thus may be modeled either separately as "main effects" (e.g. Beckman, 2006; Phillips, 2002; G roysberg et al., 2009; Wezel et al., 2006), or may be interacted to examine "moderating effects" (e.g. G roysberg et al., 2008). We extend on these studies by explicitly theorizing mediation hypotheses that recognize the endogeneity of the team size and team tenure variable to founder quality.

\section{Founder Q uality, Team Size and Tenure}

While extant literature has discussed the effects of founder quality, team size and team tenure on parent and spin-out performance, the process leading to the decisions of individuals to move with a founder to a new venture has received relatively less attention. Across all start-ups, Wasserman (2012) underscores that in seeking potential candidates for co-founders and early employees, the core founder must focus on the complementary human, social and financial capital that these key individuals bring with them. ${ }^{2}$ These individuals may be identified from

\footnotetext{
2 There is significant variation in the criteria used across new ventures in the determination of who is awarded a cofounder status, and who is considered to be an early employee. For example, Andrew Grove was not a co-founder of Intel, but a very critical team member of the new venture nonetheless (Moore and Davis, 2004). On the other hand, some organizations may more easily bestow founder status, using it as a symbolic designation for all early employees (Wasserman, 2012). Researchers have acknowledged that regardless of designation, all individuals who are part of the initial startup of the organization have a critical imprinting role on the organization (Stinchcombe, 1965; Wasserman, 2012).
} 
direct contact (friends/ family and prior coworkers), indirect contact (mutual acquaintance in a network), or impersonal search (strangers identified for particular traits and abilities). Among these sets of relationships, Wasserman (2012) integrates findings across multiple studies to note that firms with founders and early hires that are composed of prior co-workers are the most enduring and likely to succeed. Primary reasons for this finding include smoother transition of existing hierarchical manager-subordinate relationships to the new venture (Rajan \& Zingales, 2001) and superior structures for decision making (Baron, Burton \& Hannan, 1996). Indeed, Agarwal et al. (2004) found that such spin-out firms not only outperform other start-ups, but incumbent-backed ventures and diversifying entrants as well.

Focusing on the context of spin-out formation, potential founders employed as an organization and their colleagues at that organization go through a matching process that ultimately determines the characteristics of the departing team. From the perspective of the individual who is the potential core founder, as defined above, key criteria for team assembly relate to the valuable complementary human, social and financial capital that each colleague delivers. G iven the riskiness of embarking on a new venture, the potential core founder is likely to seek out those colleagues that not only embody high levels of capabilities individually, but also represent strong relationship bonds that include the stable routines and trust that enable tackling tough business problems (Wasserman, 2012). However, not every founder is equally likely to attract individuals that possess these capabilities, and founders' own characteristics determine their ability to convince co-workers to leave their existing stable work environment for the uncertain option of joining a new venture.

We explore the connection between spin-out team assembly and founder quality, where founder quality may be manifested through high rank (Phillips, 2002), high ability to generate value for their firm (Campbell et al., 2012) and other indicators of "star performance" (G roysberg et al., 2008), through both economics and organizational behavior lenses. First, through the economics lens, high quality employees who are considering leaving their current employer to found a new venture have a high opportunity cost associated with founding a spin- 
out. The more highly paid a potential founder is at their current employer, the greater the expected performance of the spin-out must be in order to convince a rational founder to leave the secure job for a new venture. As a result, the opportunity cost for the founder provides a powerful signal to coworkers on the expected success of the venture (Spence, 1973). This, in turn, makes the venture more attractive to coworkers and subordinates, making them more willing to forgo their secure employment and join the new venture. This is also true for more experienced workers. Because workers with higher tenure are less likely to leave their organization (Maertz \& G riffeth, 2004), they require a stronger signal of new venture success in order to be convinced to leave their current job. As a result, higher quality founders have access to a larger and more experienced pool of potential spin-out team members which leads to superior performance and a self-fulfilling prophecy of the economic signal (Merton, 1968).

Additionally, the necessity of complementary human capital to the success of a venture may depend on the nature of tasks chosen by or assigned to the focal employee. Particularly in the context of specialized tasks ( $G$ aricano, 2000; Jones, 2009), high quality employees may be selected or assigned to solve more complex problems. Prior work has shown that higher complexity of tasks increases interdependencies among team members (Fleming \& Sorenson, 2004). Importantly, G anco (2012) showed that employee teams solving complex problems are more likely to spin-out as a team. When solving a complex task, the team members' collaborative activities are fine-tuned and even a replacement of a single team member may have a dramatic negative effect on performance (Solow et al., 2005). Consequently, founders who create value by solving complicated problems have a strong incentive to keep collaborative teams intact. Similarly, team members collaborating on complex problems may need to significantly re-align their activities if part of their team departs and they decide to stay with the current firm. Since job complexity is associated with high labor market demand (Spitz-O ener, 2006) and consequently with high wages (O phem, Hartog, \& Vijverberg 1993), higher quality employees may work on more complex tasks than lower quality employees, and these individuals will tend to have stronger incentives to spin-out with a greater proportion of their existing team. Further, 
it will be particularly beneficial to leave with those subordinates or co-workers who have longer tenure with each other, as a way of preserving the productive interdependencies and routines.

The organizational behavior literature on job embeddedness further informs the process of spin-out team formation. Job embeddedness highlights three dimensions- link, fit, and sacrifice - that impact the extent to which employees are wedded to their existing employment (Mitchell et al., 2001; Swider, Boswell, \& Zimmerman, 2011). While "link" relates to the formal and informal ties with the institution, "fit" focuses on compatibility and comfort levels, and "sacrifice" relates to the tangible and intangible benefits that may be lost upon leaving the organization (Swider et al., 2011). These three important constructs provide insights on the manner in which founder's characteristics determine the founding team size and experience. Given that employees in an established organization are more often than not organized in vertical hierarchical structures, the links that subordinates have to the organization are embodied within the links to their superior (Rajan and Zingales, 2001). Thus, individuals who are already leaders in the parent organization are more likely to convince linked subordinates to leave with them (Rajan and Zingales, 2001). Similarly, employee perceptions of fit with the organization are also intricately tied to the comfort and compatibility with their immediate superiors, as indicated by the vast literature on "leader-member exchange" or LMX (cf., Graen \& Scandura, 1987). Ballinger, Lehman and Schoorman (2010) note that subordinate employees experience significantly more negative affect and are more likely to develop tumover intentions when their leaders depart. Importantly, Camahan, Shapiro and Agarwal (2012) theorize how departing leaders, particularly with transformational qualities, are more likely to elicit their subordinates to follow them to their next destination. Finally, perceptions of sacrifice are related to the risk and uncertainty associated with leaving a stable work place to be part of a new venture. In this context, Campbell et al. (2012) note that high quality individuals have a higher ability to recreate and transfer complementary assets, including the critical complementary human capital that is required for new venture success. The demonstrated leadership traits of such individuals are more likely to convince coworkers of their entrepreneurial ability, as scholars have noted the 
similarities between characteristics of leaders and entrepreneurs (Campbell et al., 2012; Ensley, Pearce, \& Hmieleski, 2006). Thus, coworkers of high quality founders are more likely to perceive that the pecuniary and non-pecuniary returns from moving with the founder justify the decision (Carnahan, Agarwal, \& Shapiro, 2012).

Not only can high quality individuals successfully address the dimensions of job embeddedness for any one employee, given their rank and status as high performers, they are likely to be in contact with more employees, and those with longer tenure in the firm. Accordingly, they will be able to assemble a larger team, potentially with significant functional heterogeneity that has both complementary and supplementary fit. Further, they will also be able to address the link, fit and sacrifice dimensions for the co-workers with longer tenure better than individuals with lower quality. Importantly, they may also be able to create a contagion effect that promotes lift-outs of entire team members (G roysberg, et al, 2008). Accordingly, H1: Fander quality will bepositivdy redated to thesizeof thespin-at tem H2: Fander quality will bepositivdy rdated to thetenure of thespin-at team

\section{Mediation of Founder Q uality - Firm Performance Relationship by Team Size}

A founder's ability to depart with teams of larger sizes will have important performance implications for both the parent and the spin-out firm. For the parent firm, while losing a "star" employee implies a significant loss of human capital, the performance effects may be driven by the individual's ability to recreate and transfer complementary assets (Campbell et al., 2012), thus increasing the competitive rivalry ramifications for the parent. The size of the team represents a greater transfer of rival resources than the simple additive effect of the resources of each individual team member. Because the core founder chooses the team members in order to maximize the value of the new firm, the synergies and complementarities between the founder and other team members will have a superadditive effect which increases with team size.

First, when departing with teams of larger size, high quality individuals not only take the tacit knowledge possessed by each departing employee, in a professional services context they 
also transfer the personal relationships with suppliers, complementors and clients. Importantly, aside from the additive effects of the transfer of each departing team member's human, social and financial capital, a founder who leaves with a team versus alone adversely impacts the parent firm for reasons directly related to the team formation. As indicated above, when starting a new venture, core founders need to not only select who among their coworkers may be best for the new venture, but also have to convince them to leave their existing employment. The selection and matching process thus requires significant vetting of each other by all departing team members. Founders that are able to assemble larger teams leave with more comprehensive knowledge breadth and depth, since departing teams may be constructed to optimize on linkages within and across specialized skills (Horwitz \& Horwitz, 2007). Accordingly, it will be more costly for the parent firm to replace the knowledge embodied by high quality individuals who take a team of employees that works in concert to create value. In other words, the negative impact of the core founder's departure is the result of entire team's exit and not just the departure of the individual. As a result, we posit a mediating relationship: the effect of founder quality occurs through the size of the team the founder assembles.

For spin-outs, we expect that greater transfer of resources when founders assemble a larger team will have a positive effect on performance. Critical factors impacting new venture survival are its resource endowments and its perceived legitimacy and reputation. Founder quality affects these factors through the ability to assemble a larger team that permits a greater transfer of resources and relationships from the parent firm to the spin-out and more individuals contributing to the development of valuable organization capabilities. Further, larger team size allows the core founder to optimally configure the resources and knowledge embodied in each team member through the definition of roles, and the development of routines for generating organizational knowledge through specialization of members that can then focus on specific roles and generate task-specific skills (Sine et al., 2006). Externally, the ability of a new venture to learn from other firms increases with the size of the start-up (Almeida, D okko, \& Rosenkopf, 2003), so founders who assemble larger teams are able to acquire more knowledge than founders 
with smaller teams. Together, these factors indicate that the ability of founders to access knowledge is driven through their ability to assemble a large team.

In summary, while prior literature suggests that the quality of the founder will enhance the performance of her new venture and harm the performance of her departing firm because of her superior individual skills, we argue that higher quality founders beget higher quality spin-outs and have a larger adverse impact on their parent firms because they are able to attract more individuals to their young, uncertain organizations (Alvarez \& Barney, 2005). Combining the effects on parent and spin-outs yields:

\section{H3: Temsizemedates (a) thenegative ffeet of founder quality on sarcefimmpefommaneand(b) thepositive ffeet of foundar quality on spin-ait pefomance}

\section{Mediation of Founder Q uality- Firm Performance Relationship by Team Tenure}

In line with the previous logic, the adverse impact of departing founder quality on parent firm performance occurs not only through the loss of the departing key individual, but through the characteristics of the team the departing founder assembles. Previous literature has established that the performance of both parent and spin-out firms are affected by the longevity of experience embodied in the departing team that the founder is able to assemble. As in the prior literature, we assume that the longer the individual team members were employed at the parent, the greater is the knowledge of routines and procedures of the parent firm possessed by the team members (Beckman, 2006; Phillips, 2002; Wezel et al., 2006). Because routines reflect "experiential wisdom" (G avetti \& Levinthal, 2000) and are associated with learning-by-doing (Argote et al. 1990, Becker 2005), when founders leave with employees that have larger accumulated experience in an organization, they are better able to replicate the routines from their parent to the spin-out. The greater the tacit knowledge embedded in the firm specific routines, the longer it will take for employees to acquire the requisite managerial skills and organizational capital. Thus, a founder's ability to assemble teams that have longer team experience will critically determine to the extent to which important parent firm-specific knowledge can be replicated at the spin-out. 
When founders depart with teams with longer tenure, their ability to replicate firm routines, norms and procedures within a spin-out organization will increase competitive pressure on the parent organization (Aime et al. 2010; Wezel et al, 2006), especially if the new organization is competitively "close" to the parent firm and may target the same customers. The greater the tenure of the team departing with the core founder, the more likely the spin-out's routines and procedures will resemble the ones of the parent, and the greater the adverse impact on the parent firm. Thus, because higher quality founders can assemble a more experienced team, another mechanism through which founder quality impacts parent firm performance is the ability to attract experienced team members.

For spin-outs, a necessary condition for a new venture's success is for the founder to be able to establishment norms, routines and structures within which resources can be appropriately configured. Sine et al. (2006) find that start-ups that have better developed structures and routines are more likely to be successful given early imprinting effects (Stinchcombe, 1965). Thus, in addition to the human capital available within the spin-out, the ability to replicate routines, norms and procedures is critical (Phillips, 2002; Wezel et al., 2006; Aime et al., 2010), and the managerial skill and the tacit knowledge of how to set-up and run an organization may be particularly useful within the context of the start-up firms (Mostafa \& Klepper, 2010; Sine et al., 2006). As a result, founders who are able to transfer teams with longer tenures have a head start on many of the critical organizational and structural hurdles encountered in the nascent years of the start-up. We thus anticipate that founders that assemble teams with longer tenure will have higher performance. Analogous to our prior hypothesis, the benefits to spin-out performance that are associated with a high quality founder partially occur through her ability to attract teams that share longer experience rather than only through her direct effect on the decisions of the start-up. Together, this implies:

H4: Temtenuremediates (a) thenegalive ffet of founder quality on sarcefimpeformanceand (b) the positiveeffett of founder quality on spin-ait peformance 


\section{DATA AND METhOdology}

\section{Context: The U.S. Legal Senvices Industry}

We used data from the legal services industry, which is a knowledge intensive industry where human assets are easily mobile and are the most important input in value creation and appropriation to test the hypotheses. D ue to high human capital intensity, the flow of knowledge via mobility across organizational boundaries is much easier than in manufacturing industries. This reflects the importance of knowledge compared to physical assets in the creation of value (Teece, 2003). Examining our research questions in the legal services context thus allows us to isolate the factors related to the creation of entrepreneurial teams while abstracting away from other factors that may affect spin-out formation in manufacturing industries like technology (Agarwal et al., 2004). Further, there are very few barriers to entry and employee mobility in this industry because non-compete clauses are not enforceable and individuals who have the necessary credentials are able to easily move between firms or create new ones. ${ }^{3}$ Since employers cannot prevent the movement of human assets, spin-out generation is more likely to occur in professional services than in manufacturing where physical capital is more important to value creation compared with human capital (Teece, 2003). As a result of these factors, this industry provides us with a rich dataset on spin-out formation.

Studying professional services is also important because of their prominent and growing role in the U.S. economy. In the middle of the last century, there was a shift from manufacturing to services (Baumol, 1967, Fuchs, 1968). D ue to this change, the service sector has grown to account for almost half of the U.S. GDP, while manufacturing sector has shrunk to less than half the service sector's size (BEA, 2008). In addition, a significant portion of this change is due to the growth in professional services (Buera \& Kaboski, 2012).

\section{Data Source}

The data are from a custom extract that contains linked employer-employee records drawn from state-level unemployment insurance (UI) records as well as several data products

\footnotetext{
${ }^{3}$ Given state-specificity of bar exams, lawyers' credentials are more transferable within than across state borders. Thus, the direct costs of mobility and of new firm generation are low within states in this industry.
} 
from the U.S. Census Bureau which comprise the Longitudinal Employer-Household Dynamics (LEHD) Project available at the Census Research D ata Centers. Employers provide their state with a form ES-202 which lists all active employees covered under the UI program, their taxable earnings, and the firm's characteristics each quarter. The LEHD project constructs two types of longitudinal records, those that include information for all employees under the UI program, including employer name and taxable earnings for all employment "spells" (periods), known as employmet histary files and longitudinal records of all firm-level characteristics, emplgyer daracteistic files from these mandatory submissions. In addition, the indvidual daradeistics files append demographic information, including race, ethnicity, gender, age, and education. These files are either drawn or imputed from the Social Security Administration's “Personal Characteristics Files," the Decennial Census, the Current Population Survey, and the Survey of Income and Program Participation. By combining these data files, we have detailed information on individual employees and firm level characteristics, along with the history of all employee-employer dyads.

O ur data identify all individuals employed in U.S. legal services over more than 40 quarters in ten large states. Since the data are drawn from mandatory filings, they cover the entire universe of legal services firms in the ten states. This universality permits us to track interfirm employee mobility and to identify new firms.

These data are particularly valuable for studying entrepreneurial processes in the legal services industry for two key measurement reasons. First, these data allow excellent measure of firm performance in the legal services context. Most law firms are organized around the partnership model; the partners are the principals in the firm and almost all revenues are paid out to the employees, which include partners, as taxable earnings. ${ }^{4}$ The division of the firm's profits among partners is typically either allocated through equal shares or based on the individual's contribution to the firm's profit ( $G$ ilson \& Mnookin 1985). The dominance of the partnership models allows measurement of firm performance using only data on employee

4 There are three main groups of employees: staff which includes administrative assistants, secretaries and paralegals; associate lawyers and non-equity partners; and equity partners. Equity partners are typically lawyers who have been promoted after six to ten years of practicing law and receive a share of profits. 
compensation. In the partnership model, the sum of all compensation paid out by a firm is a close proxy for the revenues collected by the firm.

Second, our analysis requires a measure of founder quality where quality is a multidimensional construct that includes rank (Phillips, 2002; Rajan \& Zingales, 2001; Wezel et al., 2006), ability to generate value for their firm (Campbell et al., 2012) and other indicators of "star performance" (G roysberg et al., 2008; G roysberg et al., 2009). However, existing literature demonstrates that each of these dimensions of quality correlate strongly with earnings: earnings are positively related to superstar performance (Rosen, 1981) and reflect the education and experience (Mincer, 1974) and social network (Shaw, Duffy, Johnson, \& Lockhart, 2005) that allow an individual to generate value for an organization. Further, earnings are positively related to the role of an individual within the hierarchy of the firm (Levine, 1993; O'Reilley, Main, \& Crystal, 1988) and thus reflect the rank of individuals within an organization. As such, the accurate measures of earnings embodied in the data can serve as a proxy for the broad array of attributes that reflect founder quality in this context.

For the empirical analysis, we construct two frames of data. We construct a panel of parent firms (i.e. established firms that generated a spin-out in the prior period) where each observation represents a parent-firm year in which an established firm spawned at least one spinout. This frame allows us to measure the immediate effect of losing a founding team on parent firm performance. To construct the parent firm sample, we begin with excluding very small firms (less than five people) to eliminate their effects on the measured impact of mobility on firm performance. We also exclude outlier firms with revenues per employee of less than $\$ 10,000$ or more than $\$ 1,000,000$ and firms that lost or gained more than 500 employees in any payroll class to an established firm or to a spin-out in a given year. The latter restriction allows us to exclude mergers, acquisitions, and administrative recoding of organizational identifiers. ${ }^{5}$ It is also important to ensure that departures of employees are not being dictated by impending

\footnotetext{
${ }^{5}$ An administrative recode is when the data collection agency changes a firm's identification number. Administrative recodes appear in the data to be large mobility events where all of a firm's employees move from an existing firm to a new firm. Inclusion of these events would contaminate our measures of mobility to spin-outs.
} 
firm death. Consequently, we condition our sample on healthy established firms by eliminating any observations where the firm dies within the next two years.

For the spin-out firm sample, we begin by identifying those start-ups for which at least one employee appeared in the payroll of an existing firm in our data in the preceding year. Approximately 10,000 spin-outs meet this criteria. We then construct a panel that includes yearly observations on all spin-outs till they time that they exited, or the last observed year in our data.

\section{Variables}

In constructing our tests, we aggregate the employee-level data to the parent firm and spin-out firm level and construct the following variables:

Parent firm performance: Since partners typically divide up the firm's profits and receive this as taxable income, we measure parent firm performance by examining the sum of taxable income paid to the firm's employees. This gives us a measure of firm's total revenues (less non-compensation costs and set-asides for future years). Consistent with prior work (Campbell et al., 2012), in order to adjust for firm size, we used the firm's average total revenues, which is the firm's revenue per employee. This allows us to compare the productivity of firms of different sizes, and examine the revenue effect associated with the loss of the spin-out team. ${ }^{6}$ To avoid estimating a spurious relationship between the departure of highly paid individuals and subsequent revenue per worker, we measure revenue per worker in the following year and include new hires in the measurement. Our estimation is thus rather conservative as it incorporates replacement hires as well as those who were retained.

Spin-out firm performance: $N$ ew ventures invest a large share of their revenues in developing future business opportunities. Because the share of their revenues that start-ups invest in this activity may vary greatly across firms, revenues are a very noisy measure of spin-out performance. To measure spin-out performance, we follow extant studies (Agarwal et al, 2004; Wezel et al, 2006; Phillips, 2002) and focus on survival, since it is a more accurate capture of the

${ }^{6}$ In general, survival rate increases with firm age (e.g., Agarwal and G ort, 1996) with the heterogeneity occurring more in terms of financial performance. 
primary objective of the newly founded organization. We construct a dummy for "failure" which takes the value of 0 if the spin-out does not exit the data in the next year and 1 if it does.?

F ounder quality: We use the earnings of the founder of the spin-out team as a proxy for founder quality. To operationalize this measure, we identify the founder as the spin-out team member that had the highest earnings while employed at the source firm among all individuals in the departing team, and thus appropriated the greatest value from their employer in the previous year. This individual represents the team member most likely to have the greatest authority and responsibility at the previous employer. For parent firms that experienced more than one spinout event in a year, we compute an average of the earnings of the founders across these events.

Spin-out team size. To capture the extent to which prior colleagues follow the founder we count all individuals who moved with the leader from the parent firm to the focal spin-out in the same calendar year. For parent firms that experience multiple spin-out events in a particular year, we averaged the team size across the different spin-outs for that year.

Spin-out team tenure. We capture the experience of the spin-out team based on the number of years the departing team was at the parent firm. We calculated the measure as the average tenure at the parent firm for the departing team members to the focal spin-out. As above, if a parent firm experienced more than one spin-out in any one year, we compute the simple average of this measure across all spin-out events for that year.

Control variables. In our parent performance estimations, we include a firm fixed effect, several time-variant firm-level controls, and several local labor market controls, and we also control for the means of the demographic variables measured over all of a firm's employees and for only the exiting employees. Specifically, we include controls for firm age, firm size and a lagged dependent variable to control for prior performance. At the local market level, we control for the number of other firms in the Metropolitan Statistical Area (MSA) and also the revenue

\footnotetext{
${ }^{7}$ In the spin-out analysis, we measure firm performance as survival and in the parent data we measure firm performance as revenue per worker. We consider survival to be a more appropriate measure of performance of spin-out firms than revenue per worker because income-based measures may not reflect true performance when examining entrepreneurial start-ups (Campbell, 2012). Further, analysis of spin-outs using revenue per worker would condition our estimation on better surviving firms.
} 
variation across firms in the local MSA. We add controls for employee demographic characteristics such as mean age, racial and gender composition of the firm and mean education in the last quarter of each year. We also include controls for the characteristics of the employees that left the firm in the prior year. Specifically, we include controls for the number of individuals who left the firm, as well as the education, age, and gender of these employees. We also control for the effect of general exit, i.e. the effect of all exiting employees, regardless of whether they joined a spin-out or an existing firm after leaving the parent firm. To do so, we included counterparts of the explanatory variables measured for all exiting employees - team size, average tenure and earnings for all exiting employees.

In our spin-out survival estimations, we control for factors that may correlate with survival and spin-out team characteristics. We include controls for the size of the spin-out at entry to control for founding employees that came from other parent firms and also current size of the spin-out. We control for the size and age of the parent firm to capture the level of resources available at the prior employer. ${ }^{8}$ We also include controls for quadratic terms for age of the spin-out to account for differences in hazard rates over time. Finally, to capture competitive effects, we control for the number of other firms in the Metropolitan Statistical Area (MSA) and include year fixed effects to control for changes in conditions across years.

Table 1 gives descriptive statistics and correlations of the parent firm sample and Table 2 provides summary statistics and correlations of the spin-out data.

\section{Estimation Methodology}

We estimate panel regression models that capture the relationship between the mediators and the spin-out founder earnings in hypotheses 1 and 2. We employ linear panel regression for parent firm performance after a spin-out event, and a cloglog model specification for spin-out survival to test hypotheses 3 and 4 . In the parent sample, we utilize parent firm fixed effects to

\footnotetext{
${ }^{8}$ Some firms with high tumover will tend to produce over-counting of employees, resulting in biased year averages of employment. In order to minimize this possibility, we calculate size of the parent firm as employment during only the first quarter of the year.
} 
capture unobserved heterogeneity. In the spin-out sample, we estimate the effect of timeinvariant spin-out team characteristics on survival which precludes us from using fixed effects.

To conduct our tests for mediation, we follow the Baron and Kenny (1986) framework and further confirm the analysis using the Sobel (1982) test and the MonteCarloMethodfor AssessingMedation(MCMAM, Selig \& Preacher, 2008).

\section{RESULTS}

We provide tests of hypotheses 1 and 2 in Tables 3 and 4. In Tables 5 and 6, we present the test of the relationships between founder quality and parent firm and spin-out performance without any mediators. In Tables 7 and 8 , we provide the results of the mediating effects of team size and team tenure on the effect of founder quality on parent firm and spin-out performance (testing hypotheses 3 and 4). Table 9 contains test statistics of the mediation models.

In Table 3, models 1 and 2 demonstrate the relationship between spin-out founder quality and spin-out team size and spin-out team tenure using the parent firm sample. The model includes firm and year fixed effects as well as other time varying controls as described above. In both models, the positive and statistically significant coefficient of founder quality indicates that higher quality founders attract larger teams of followers and more experienced followers. While the analysis in Table 3 aggregates across the multiple spinout events within and across years for each parent, the results in Table 4 provide similar evidence for the spin-out sample. In Table 4, the focal unit of analysis is a single spin-out, and models 1 and 2 provide estimates of a panel regression where spin-out team size and team tenure respectively are a function of founder quality, and controls relevant to the spin-out sample. In line with the results using the parent firm data, there is a strong significant relationship between founder quality and the size and tenure of the team they assemble. Thus, regardless of whether one focuses on the founder quality compared to all other founders within a parent firm (Table 3), or founder quality compared to other founders of all spinouts (Table 4), these findings provide strong support for Hypotheses 1 and 2. 
We next provide tests of the mediation framework. Tables 5 and 6 show the direct effect of founder quality on the parent and spin-out performance in the absence of the mediating variables. The strong and significant negative relationship between founder quality and parent firm performance in Table 5 is consistent with prior work that shows that the higher the quality of an employee leaving for a new venture, the greater the adverse effect on firm performance (Campbell et al., 2012). In Table 6 where the dependent variable is spin-out firm failure, the significant negative coefficient on founder quality is consistent with prior studies documenting the beneficial impact of founder quality on spin-out performance (e.g., Gimeno et al., 1997; Phillips, 2002). These results demonstrate support for the first condition of mediation: that the independent variable of interest is significantly related to the dependent variable of interest (Baron \& Kenny, 1986). Note that our tests of hypotheses 1 and 2 above indicate support for Baron and Kenny's second condition for mediation, showing that the independent variable of interest is in fact related to the potential mediators.

Table 7 presents the full model that includes both the independent variable of interest and each of the mediators as they affect parent firm performance. Model 1 includes just the spin-out team size potential mediator, model 2 contains just the spin-out team tenure potential mediator and model 3 includes both potential mediators. In model 1, the effect of departing spin-out team size on parent firm performance is strongly negative and significant even in the presence of founder quality, and the coefficient on founder quality becomes insignificant. This indicates support for the third condition in the Baron and Kenny approach. The estimates of model 2, however, indicate that the tenure of the team that moves with a departing founder have no measureable effect on parent firm performance and thus violates the third condition of mediation. In model 3, spin-out team size is strongly significant while neither founder quality nor the tenure of the departing team is significant. Results in Table 7 are thus consistent with hypothesis 3a but not with hypothesis $4 \mathrm{a}$.

Table 8 presents the full mediation model for spin-out performance. Model 1 includes only the spin-out team size potential mediator, model 2 includes only the spin-out team tenure 
potential mediator and Model 3 includes both potential mediators. In models 1 and 2, the potential mediators are individually negatively related to spin-out failure even when controlling for founder quality, and the coefficient on founder quality is smaller in magnitude than in the model without mediators presented in Table 6 . Model 3 of Table 8 presents the full model with both potential mediators. The results are consistent with a full mediation model where both potential mediators are negatively related to spin-out failure and the effect of founder quality loses statistical significance. Together, the results support the conditions necessary for the presence of a mediation effect of spin-out team size and spin-out team tenure on the effect of founder quality on spin-out performance - supporting hypotheses $3 \mathrm{~b}$ and $4 \mathrm{~b}$.

We further performed the Sobel (1982) test and MCMAM (Selig \& Preacher, 2008). The results of the tests are in Table 9. The z-score column contains the Sobel test statistic. The last column in the panel contains the lower and upper bounds of a 95\% confidence interval on the indirect effect using MCMAM with 20,000 repetitions. Under the assumption that the coefficients of interest in the models have normal sampling error, random draws from the distributions of the coefficients are performed to simulate the magnitude of the indirect effect and a confidence interval is then constructed from these simulations. We first examine the effect of mediators on the parent firm performance (H3a and H4a). The results in Tables 3 and 7 suggest that spin-out team size satisfies the requirements for mediating the relationship between departing leader quality and parent firm performance, while spin-out team tenure does not satisfy the requirements of mediation. The tests in the bottom panel of Table 9 emphasize these results. The results demonstrate the z-score of the Sobel test is strongly significant for spin-out team size and is insignificant for spin-out team tenure and the MCMAM simulation suggests the confidence interval of the indirect effect associated with spin-out team size is statistically significantly different from zero, while the indirect effect associated with spin-out team tenure is not different from zero. This allows us to reject the null hypothesis that spin-out team size has no indirect effect, but we cannot reject that spin-out team tenure has no indirect effect. Thus, these test results are consistent with hypothesis 3a but not with 4a. 
Examining the effect of mediators on the spin-out firm performance (H3b and $\mathrm{H} 4 \mathrm{~b})$, we find that for each potential mediator, the Sobel test statistic is significant at the 1\% level rejecting the null hypothesis that there is no indirect effect. For both mediators, the $95 \%$ confidence interval does not include zero which, consistent with the Sobel test allows us to reject the nullhypotheses that there is no indirect effect. The data provide strong evidence of the presence of a mediating effect of spin-out team size and tenure on the relationship between founder quality and spin-out performance. This provides further support for hypotheses $3 \mathrm{~b}$ and $4 \mathrm{~b}$.

In summary, the results are robust across multiple tests of the hypotheses. We find strong support for the hypotheses that founder quality impacts the departing team size and team tenure. Further, team size mediates the effect of founder quality on both parent and spin-out firm performance. However, team tenure mediates only the effect of founder quality and spinout performance.

\section{DiscuSSION AN D CONCLUSION}

Within the rich literature on the competitive dynamics of parents and spin-outs, scholars have explicitly examined the effects of founder quality, founding team size and team tenure on firm performance (Beckman, 2006; Campbell et al. 2012; Groysberg et al, 2008; 2009; Klepper \& Thompson, 2010; Phillips 2002, Wezel et al. 2006). While collectively the scholarly work points to a very consistent adverse effect on parent firm performance and a consistent beneficial effect on spin-out firm performance, each of these studies have examined the effects of the three variables largely in isolation of the others. In doing so, these studies make the implicit assumption that departing team size and team tenure are determined independently of founder quality, and thus may be modeled either separately as "main effects" (e.g. Beckman, 2006; Phillips, 2002; Groysberg et al., 2009; Wezel et al., 2006), or may be interacted with founder quality to examine "moderating effects" (e.g. G roysberg et al., 2008). In contrast, we develop a theoretical framework that explicitly recognizes that founders with greater ability have a higher likelihood of assembling teams that have the right mix of complementarities and experience, and thus, team size and tenure mediates the effect of founder quality of both parent and spin-out 
performance. We test our hypotheses in the context of the legal services industry-a professional services context where employee mobility is critical to knowledge transfer and replication - and use the longitudinal and comprehensive linked employee-establishment data compiled in the Census LEHD project for our analysis.

The empirical analysis supports almost all the hypothesized relationships. Founders with higher observed quality are more likely to assemble a team that is larger (hypothesis 1) and with higher tenure (hypothesis 2). Further, our results strongly support the mediating effect of team size on the negative relationship between founder quality and parent firm performance (hypothesis 3a), and the positive relationship between founder quality on spin-out performance (hypothesis 3b). Finally, the results fail to support the mediating effect of team tenure on founder quality and parent firm performance (hypothesis 4a), but show strong support for team tenure mediating the founder quality and spin-out performance relationship (hypothesis $4 \mathrm{~b}$ ).

O ur results highlight the importance of understanding the linkages between founder quality and team characteristics. Rather than simply using either founder quality or team size and experience, we show that a richer model based on the interplay of these characteristics will provide us with a deeper understanding for how these factors impact both parent and spin-out performance. In particular, our results show that attributing the negative impact on the parent firm and the spin-out success to founders directly neglects their impact on these outcomes due to their ability to assemble a team of complementary skills and experience. Higher quality founders are both better able to identify complementary human assets and better able to convince human assets to join them.

O ur large scale quantitative results are consistent with the anecdotal evidence that motivated the study. While the stories of Robert Noyce and Gordon Moore serially founding Fairchild Semiconductor and Intel with critical other employees are legion (e.g. Gordon and Moore, 2004) other, perhaps lesser known, examples are also very illustrative. No doubt, Walt Disney's individual characteristics played an important role in Ub Iwerks' willingness to forgo a steady job at Pesman-Rubin Commercial Art Studio in his hometown of Kansas City, and 
venture to California when Disney approached him with his entrepreneurial ambitions. In turn, the early and turbulent years for D isney witnessed Iwerks' steadfastness to the founder, even as D isney lost the ownership rights to the Mickey Mouse precursor "O swald the Lucky Rabbit" to distributor Charles Mintz, who further hired away most of Disney's key animators (Gabler, 2006). The complementarities and longstanding trust within the team of two played a critical role in D isney, Inc.'s ultimate success. Similarly, Johnson and Johnson was created by brothers, Edward M. Johnson and James W. Johnson, who had sales and engineering backgrounds respectively at parent firm Seabury and Johnson. Seabury and Johnson was actually started by a thirdbrother, Robert W. Johnson. The complementary skills of the founders and the early hires of Robert W. Johnson and 14 other Seabury and Johnson employees were critical to the ultimate demise of Seabury and Johnson, and to the spectacular success of Johnson and Johnson. In this case, Edward M. Johnson and James W. Johnson had high rank and quality, which combined with familial bonds and prior work experience, helped recruit the employees who had important complementary skills and experience from the surgical dressings business unit of Seabury and Johnson (Kilmer House, 2012).

Thus, our study highlights the importance of the founder's quality in attracting employees to a new venture. Because of the relative uncertainty associated with new ventures (A garwal \& Audretsch, 2001), employees are understandably leery about leaving an incumbent for a spin-out. In this context, the founder's ability to recognize and exploit new opportunities, as well as the ability to assemble a team with the necessary complementary skills to do so help to determine which employees and how many will join the start-up. Indeed, given this connection between the founder's quality and the start-up team, we posit that the theoretical models in prior studies that include founder or team characteristics alone are mis-specified.

In addition to highlighting the effect of team formation on the performance of spin-outs and parents, our study also has important implications for the transferversus spillower effects of the knowledge between parent and spin-out firm performance. In this context, the lack of support for Hypothesis 4a, while all other hypotheses are strongly supported is particularly 
interesting. Since team size represents a transfer of rival resources from the parent to the spinout, the symmetric support for Hypotheses 3a and 3b indicates that gains in spin-out firm performance are at the expense of the parent firm. Because better founders may be able to attract more employees from the parent firm due to higher opportunities or advantages relative to the parent firm., the size of the team reflects not only the additive influence of individuals leaving enmasse but also the effect of selection and synergies in the team composition: larger teams imply that these employees are walking out with better opportunities and better configured resources. However, to the extent that team tenure and experience are a loose proxy for the knowledge of routines and practices implemented in the organization, and thus accessible to both organizations simultaneously, its effects represents the impact of replication of non-rival knowledge or spillower of knowledge from the parent to the spin-out. The lack of support for $\mathrm{H} 4 \mathrm{a}$ while there is strong support for $\mathrm{H} 4 \mathrm{~b}$ then indicates that parent firms are not necessarily hurt even as spin-outs benefit from knowledge spillovers. The parent firm is relatively unaffected, beyond the transfer of personnel, by the experience embodied in the departing team. Nonetheless, for a spin-out, the effect of additional team experience is as important as the team size. Thus, our study is able to shed light on the differential effects of transfer vs. spillover of knowledge on parent and spin-out firms respectively.

O ur research has a number of limitations, several of which may be fruitful avenues for future work. First, our results are based on a single industry. While there are a number of other industries that are similar to this one, such as advertising, accounting and consulting, the legal services industry has several features that are atypical of other industries such as manufacturing. O ur results may not fully extend to manufacturing because of the higher cost of starting up a firm and the complementary assets are more likely to be embodied in the production process itself. That being said, the hypothesized theoretical mechanisms likely apply across industries even though the spin-out rate may be lower in some other settings. Second, we do not measure direct competitive interactions between the parent and the spin-out. In particular, since we do not have access to the specialties of the team members, or other measures of the actual 
knowledge possessed by team members, we cannot compare the spin-out's set of specialties or knowledge base with that of the parent firm. Third, we cannot measure the opportunity pursued by the spin-out founder. While founders with higher earnings would require an opportunity with higher expected value to convince them to leave their established firm than a founder with lower compensation at the parent firm, we cannot directly infer any information on the size of the opportunity. This is an important limitation because the magnitude of the exogenous opportunity may be an omitted variable that drives the results. An alternative explanation is that higher quality opportunities are pursued by a larger and higher quality pool of employees. As a result, better opportunities lead to both higher quality founders and bigger and more experienced teams, as well as positive outcomes for spin-out success and negative outcomes for the losing parent firm. Another related concern is that the employees we classify as leaving incumbents voluntarily to form spin-outs may represent involuntary mobility since the focal employees are instead terminated by their employers. Such employees are likely to have lower quality in terms of unobserved characteristics. To the extent that such individuals found new firms as an employment option of last resort, the adverse effect on parent firm performance of losing these lower quality employees and their experience may understate the impact of employee entrepreneurship and our estimates are conservative tests of our hypotheses.

In addressing our questions, we contribute to the literatures in entrepreneurship and strategic human capital. In the entrepreneurship domain, our work shows the importance of modeling the process by which founders and their spin-out teams are linked and how they affect both parent and spin-out performance. This highlights the importance of richer modeling which studies more than one factor at a time in order to better understand the micro-foundations of entrepreneurship. In contributing to the extant employee entrepreneurship literature (Agarwal et al., 2004; Beckman, 2006; Klepper \& Thompson, 2010; Phillips, 2002; Wezel et al., 2006), we find that prior experience with co-workers is an important factor in determining spin-out success because founders who can create larger spin-out teams with greater prior work experience have improved performance. 
Our work also has important implications for the literature on strategic human capital. We find that the effect of founder quality on both parent and spin-out performance is due in part to the ability of the founder to assemble a large team with previous experience. Because of the salience of the spin-out team's size and previous experience, we argue that many of the previous studies have incorrectly emphasized the importance of the founder in determining firm performance relative to the importance of the founder in determining founding team composition and experience. This suggests that future work on employee mobility and entrepreneurship should focus on the dynamics of team formation that individual founders may harness, rather than the individual attributes of the founders themselves.

The mediating effect of complementary human assets leads to important practical implications for both spin-out founders and for managers of established firms faced with the threat of losing employees to a new venture. For spin-out founders, our results highlight the importance of both attracting a larger team and one with higher experience. While much of the entrepreneurship literature highlights the role of founders, a key mechanism through which founders affect the potential success of their ventures is assembling a strong, productive team. As a result, potential founders who are unable to attract colleagues to move with them to their new venture should reconsider founding a new venture. The ability to attract colleagues is an important validation of the opportunity identified by the potential founder and of the ability of the leader to exploit that opportunity. If founders are unable to convince colleagues to leave their current jobs for the risk and uncertainty of a new venture, they are unlikely to be successful despite their own quality and confidence in the opportunity. In assembling a new team, founders must be cognizant of the interaction between their own quality and the team's quality. By developing links with co-workers and other potential team members at work, founders can increase the likelihood of success of their entrepreneurial venture. So, individuals who are interested in becoming entrepreneurs should start early in making connections with co-workers and developing these relationships as well as determining which co-workers have important 
complementary skills for the future venture. This highlights the value of developing social networks and enhancing leadership skills to potential founders.

For managers of parent firms that face the threat of an employee leaving to start a new venture, the mediating effect we identify sheds light on a powerful tool for minimizing the impact of losing a spin-out founder. Instead of investing in costly mechanisms that identify and discourage potential entrepreneurs, parent firms can take a more focused and reactive approach and target potential followers after a founder leaves the parent firm. Instead of discouraging potential entrepreneurs from establishing new ventures, the new goal may be to limit the founder's ability to assemble a team from their fellow employees at the parent firm. This could, in turn, be cost effective since team members typically receive lower pay relative to founders. By providing team members who provide important complementary assets to the founder with a retention package, the firm could simultaneously lower the adverse effect of the spin-out and the costs of preventing it. This is particularly true of the most recent hires, since they often are lower paid and the effect of team experience on the parent firm's performance is insignificant. Because the departing team's size plays such an important role in the adverse effect of a departing founder on parent firm performance (Phillips, 2002; Wezel et al., 2006), managers at existing organizations should focus on identifying factors that increase loyalty and connection of team members not to each other, but to the firm at large. 


\section{REFERENCES}

Agarwal, R., \& Audretsch, D ., 2001. D oes entry size matter? The impact of life cycle and technology on firm survival. J. of Industrial Econ 49(1): 21-43.

Agarwal, R., Echambadi, R., Franco, A. M., \& Sarkar, M. B. 2004. Knowledge transfer through inheritance: Spin-out generation, development, and survival. Acad ManagenetJ. 47(4): 501522.

Agarwal, R., \& G ort, M. 1996. The evolution of markets and entry, exit and survival of firms. TheReiewof EcommicsandStatistics 78(3), 489-498.

Aime, F., Johnson, S., Ridge, J. W., \& Hill, A. D . 2010. The routine may be stable but the advantage is not: competitive implications of key employee mobility. StrategicManagenetJ. 31(1), 75-87.

Almeida, P., Dokko, G., \& Rosenkopf, L. 2003. Start-up size and the mechanisms of external learning: increasing opportunity and decreasing ability? Res Pdigy32(2): 301-315.

Alvarez, S. A., \& Barney, J. B. 2005. How do entrepreneurs organize firms under conditions of uncertainty? Jaumal of Management, 31(5), 776-793.

Argote, L. , Beckman S. L., \& Epple D. 1990. The persistence and transfer of learning in industrial settings. Managenet Sa. 36: 140-54.

Ballinger, G .A., Lehman D. W., \& Schoorman F. D . 2010. Leader-member exchange and turnover before and after succession events. Organ. Behav. Hum Deis. Procss 113, 1, 25-36

Baron, R. M., \& Kenny, D. A. 1986. The moderator-mediator variable distinction in social psychological research: Conceptual, strategic, and statistical considerations. Jaumal of Pesconalityand Social Psychdogy, 51(6), 1173-1182.

Baumol, W. J. 1967. Business behaviar, valueand gronth New York: Macmillan.

Baron, J. M., Burton, M. D ., \& Hannan, M. T. 1996. Building the iron cage: D eterminants of managerial intensity in the earlier years of organizations. Admin Sa. Quart. 64(4), 527-547.

Becker, M. C. 2005. A framework for applying organizational routines in empirical research: linking antecedents, characteristics and performance outcomes of recurrent interaction patterns. Ind CorporateChange14(5), 817-846.

Beckman, C. M. 2006. The influence of founding team company affiliations on firm behavior. Acad ManagemetJ. 49(4), 741-758.

Buera, F., \& Kaboski, J. 2012. Scale and the origins of structural change. J. OfEcon Theary 147(2), 684-712.

Bureau of Economic Analysis. 2008. Industry economic accounts program at the bureau of economic analysis. http/ / unurbea.gov.proxy2.library.uiucedu/ industry/ xls/GDPbyInd_VA_NAICS_1998-2008.xls

Burton, M.D ., Sørensen, JB, \& Beckman, C. 2002. Coming from good stock: Career histories and new venture formation. Res Soid. Organ 19 229-262. 
Campbell B. A. 2012. Earnings effects of entrepreneurial Experience: evidence from the semiconductor industry. Managemet Saience, forthcoming..

Campbell, B. A., Ganco, M., Franco, A., \& Agarwal, R. 2012. Who leaves, where to, and why worry? Employee mobility, employee entrepreneurship, and effects on source firm performance. StrategicManagementJ. 33: 65-87

Carnahan, S., Agarwal, R., \& Campbell, B. A., 2012. The effect of firm compensation structures on employee mobility and employee entrepreneurship of extreme performers. Strategic ManagementJ. fathroming

Carnahan, S., Shapiro, D ., \& Agarwal, R. 2012. When Star-Leaders Exit to Launch a Startup: Will Subordinates Follow? Working paper, University of Maryland.

Crow, D . 2009 Founders vs. Early E mployees http:/ / startupnorth.ca/ 2009/ 09/ 10/ foundersversus-early-employees/? _lsa $=\mathrm{f} 380 \mathrm{~b} 37 \mathrm{c}$

D elmar, F., \& Shane, S. 2006. D oes experience matter? The effect of founding team experience on the survival and sales of newly founded ventures. StrategicOrgan 4(3), 215-247.

D encker, J. C., G ruber, M., \& Shah, S. K. 2009. Pre-entry knowledge, learning, and the survival of new firms. Organ Sá. 20(3): 516-537.

Eisenhardt, K.B., \& Schoonhoven, C.B. 1990. Resource-based view of strategic alliance formation: Strategic and social effects in entrepreneurial firms. Org Sa. 7(3): 136-150.

Ensley, M ; Pearce, C., \& Hmieleski, K. 2006. The moderating effect of environmental dynamism on the relationship between entrepreneur leadership behavior and new venture performance Jaumal of Business Venturing21(2): 243-263

Fleming, L., \& Sorenson, O 2004. Science as a map in technological search. StrategicManagenett Jaumal, 25(8-9), 909-928.

Franco, A. M., \& Filson, D. 2006. Spin-outs: Knowledge diffusion through employee mobility. RAND J. Econom, 37(4): 841-860.

Fuchs, V. R. 1968. Theserviceeconmy. New York: National Bureau of Economic Research; distributed by Columbia University Press.

Gabler, N. 2006. Walt Disney: TheTrumph of theAmeican Imagnation New York: Random House (Knopf Publishing).

Ganco, M. 2012. Cutting the G ordian knot: The effect of knowledge complexity on employee mobility and entrepreneurship. Working paper, University of Minnesota.

Garicano, L, Hierarchies and the organization of knowledge in production, Jamal of Pditical Economy, 108, 5, O ctober 2000

Gavetti, G., \& Levinthal, D . 2000. Looking forward and looking backward: Cognitive and experiential search. Admin Sa. Quart. 45(1), 113-137.

Gilson, R., \& Mnookin, R. 1985. Sharing among the human capitalists: An economic inquiry into the corporate law firm and how partners split profits. StanfordLawRev. 37 313-392.

Gimeno, J., Folta, T.B., Cooper, A.C., \& Woo, C.Y. 1997. Survival of the Fittest?

Entrepreneurial Human Capital and the Persistence of Underperforming Firms. Administrative SaienceQuartely, 42(4): 750-783. 
Graen, G. B., \& Scandura, T. A. 1987. Toward a psychology of dyadic organizing. Rearchin Organizational Behavior, 9, 175-208.

Groysberg, B., Lee, L., \& Nanda, A. 2008. Can they take it with them? The portability of star knowledge workers. Mamagement Sa. 54(7): 1213-1230.

Groysberg, B., Nanda, A., \& Prats, M. 2009. D oes individual performance affect entrepreneurial mobility? Empirical evidence from the financial analysts market. J. Finamial Transformation 25(March): 95-106.

Horwitz, S. K., \& Horwitz, I. B. 2007. The effects of team diversity on team outcomes: A metaanalytic review of team demography. J. Management 33(6): 987.

Jones BF. 2009. The burden of knowledge and the "death of the renaissance man": Is innovation getting harder? Reviewof Econamic Studies 76,(1): 283-317.

Kilmer House. 2012. TheStary of Jdhnson andJdhnsonandits Peedehttp:/ / www.kilmerhouse.com

Klepper, S., \& Sleeper, S. 2005. Entry by spinoffs. Management Sa. 51(8): 1291-1306.

Klepper, S., \& Thompson, P. 2010. "Disagreements and intra-industry spinoffs," Intemational J. of Industrial Org, 28(5): 526-538.

Levine, D . I. 1993. What do wages buy? Admin Sà. Quart, 38(3): 462-483.

Maertz, C. P., \& G riffeth, R. W. 2004. Eight motivational forces and voluntary turnover: A theoretical synthesis with implications for research. J. of Managemet, 30(5): 667-683.

Merton, R. K., 1968. Social theryand soial sturture Free Press.

Mincer, J. (1974). Sdhoding ExperieneandEamings New Y ork: Columbia Press.

Mitchell, T. R., Holtom, B. C., Lee, T. W., Sablynski, C. J., \& Erez, M. 2001. Why people stay: Using job embeddedness to predict voluntary turnover. Acadamy of ManagemettJaumal, 44:1102-1121.

Moore G \& D avis K. 2001. Learning the Silicon Valley way. Unpublished manuscript prepared for the CREEG Conference Silicon Valley and its Imitators, Stanford University, Palo Alto, CA.

Mostafa, R., \& Klepper, S. 2010. Industrial development through tacit knowledge seeding: evidence from the Bangladesh garment industry. Working Paper, Washington University, St. Louis, MO.

Nelson, R. R., \& Winter, S. G . 1982. An eddutianary theary of ecommic hange Cambridge, Mass.: Belknap Press of Harvard University Press.

Ophem, H. V., Hartog, J., \& Vijverberg, W. 1993. Job Complexity and Wages. Intemetional EcomamicReiew 34(4), 853-872.

O 'Reilly III, C. A., Main, B. G., \& Crystal, G. S. 1988. CEO Compensation as tournament and social comparison: a tale of two theories. Admin Sa.. Quart 33(2): 257-274.

Phillips, D . J. 2002. A genealogical approach to organizational life chances: The parent-progeny transfer among silicon valley law firms, 1946-1996. Admin Sa. Quart. 47(3): 474-506. 
Rajan, R.G., \& Zingales, L. 2001. The great reversals: the politics of financial development in the 20th century. University of Chicago: Chicago, IL. Y Rosen, S. 1981. The Economics of Superstars. TheAmeicanEconomicReiew 71(5), 845- 858.

Selig, J. P., \& Preacher, K. J. 2008. Monte Carlo method for assessing mediation: An interactive tool for creating confidence intervals for indirect effects [Computer software]. A vailable from http:/ / quantpsy.org/

Jason D. Shaw, D uffy, M. K., Johnson, J. L., \& Lockhart, D . E. 2005. Turnover, Social Capital Losses, and Performance. TheAcadkmy of ManagemettJamal, 48(4), 594-606.

Sine, W.D ., Mitsuhashi, H., \& Kirsch, D .A. 2006. Revisiting burns and stalker: formal structure and new venture performance in emerging economic sectors. Acad ManagemettJ. 49(1): 121132.

Sobel, M. E. 1982. A symptotic intervals for indirect effects in structural equations models (Vol. 13, pp. 290-312).

Solow, D ., Vairaktarakis, G. Piderit, S.K. and T sai, M. 2002. Managerial insights into the effects of interactions on replacing members of a team. Management Saiene, 48(8), 1060-1073.

Spence, M., 1973. Job Market Signaling. Quart. J. ofEœn 87(3): 355-374.

Spitz-O ener, A. 2006. Technical change, job tasks, and rising educational demands: Looking outside the wage structure. Jaumal of Labor Econamics 24(2), 235-270.

Stinchcombe, A. L. 1965. Social structure and organizations. In J.G . March (Ed.), Handbook of arganizations 153-193. Chicago: Rand McN ally.

Swider, B. W., Boswell,W. R., \& Zimmerman, R. D. 2011 Examining the job search-turnover relationship: The role of embeddedness, job satisfaction, and available alternatives Jaumal of AppliedPsyddogy 96(2): 432-441

Teece, D . J. 2003. Expert talent and the design of (professional services) firms. Ind Corparate Change12(4): 895-916.

Wasserman, N. 2012. TheFaunda's Dilemmas AntidipatingandAvidingthePitfalls That Can Sink a Startup Princeton University Press.

Wezel, F. C., Cattani, G ., \& Pennings, J. M. 2006. Competitive implications of interfirm mobility. OrganSa. 17(6): 691-709.

Wuchty, S., Jones, B. F., \& Uzzi, B. 2007. The increasing dominance of teams in production of knowledge. Sa. 316(5827): 1036-1039. 
TABLE 1

Summary Statistics for Parent Sample

\begin{tabular}{|c|c|c|c|c|c|c|c|c|c|c|c|c|c|c|}
\hline & Variable & Mean & Std. Dev. & 1 & 2 & 3 & 4 & 5 & 6 & 7 & 8 & 9 & 10 & 11 \\
\hline 1 & Revenue/ employee (x1000) & 67.85 & 45.15 & 1.00 & & & & & & & & & & \\
\hline 2 & Founder quality: founder earnings (x1000) & 50.632 & 77.517 & 0.32 & 1.00 & & & & & & & & & \\
\hline 3 & Spin-out team size & 1.50 & 1.69 & 0.03 & 0.28 & 1.00 & & & & & & & & \\
\hline 4 & Avg tenure, spin-out team & 1.79 & 1.89 & 0.05 & 0.20 & 0.09 & 1.00 & & & & & & & \\
\hline 5 & Average earnings, team leader, all departing employees (x1000) & 41.471 & 46.213 & 0.33 & 0.82 & 0.19 & 0.17 & 1.00 & & & & & & \\
\hline 6 & Avg team size, all departing employees & 1.31 & 1.02 & -0.01 & 0.17 & 0.57 & 0.05 & 0.20 & 1.00 & & & & & \\
\hline 7 & Total number of departing employees & 9.12 & 26.30 & 0.01 & 0.04 & -0.18 & -0.01 & 0.05 & 0.53 & 1.00 & & & & \\
\hline 8 & Revenue variance of parent firm (x1000) & 12497 & 152693 & 0.54 & 0.14 & 0.01 & 0.01 & 0.11 & 0.01 & 0.00 & 1.00 & & & \\
\hline 9 & Age of parent firm at spin-out birth & 4.67 & 2.79 & 0.05 & 0.04 & 0.05 & 0.36 & 0.05 & 0.03 & 0.03 & 0.00 & 1.00 & & \\
\hline 10 & \# firms in MSA & 1739 & 1610 & 0.17 & 0.07 & 0.01 & 0.02 & 0.08 & -0.03 & -0.01 & 0.04 & 0.14 & 1.00 & \\
\hline 11 & $(\# \text { firms in MSA })^{\wedge} 2 / 1000$ & 5617 & 9134 & 0.14 & 0.06 & 0.02 & 0.03 & 0.07 & -0.02 & -0.01 & 0.03 & 0.17 & 0.95 & 1.00 \\
\hline
\end{tabular}

Note: Sample size of all variables is 11,822 parenting years.

TABLE 2

Summary Statistics for Spin-out Firm Sample

\begin{tabular}{|c|c|c|c|c|c|c|c|c|c|c|c|c|c|c|c|}
\hline Variable & Mean & Std. Dev. & 1 & 2 & 3 & 4 & 5 & 6 & 7 & 8 & 9 & 10 & 11 & 12 & 13 \\
\hline \begin{tabular}{l|l}
1 & Spin-out fails in $(t+1)$
\end{tabular} & 0.07 & 0.25 & 1.00 & & & & & & & & & & & & \\
\hline 2 Founder quality: founder earnings (x1000) & 62.089 & 92.597 & -0.03 & 1.00 & & & & & & & & & & & \\
\hline 3 Spin-out team size at birth & 1.66 & 1.99 & -0.03 & 0.26 & 1.00 & & & & & & & & & & \\
\hline 4 Avg tenure, spin-out team & 1.54 & 1.72 & -0.03 & 0.05 & 0.14 & 1.00 & & & & & & & & & \\
\hline 5 Spin-out total size at birth & 6.31 & 63.10 & -0.01 & 0.00 & -0.01 & -0.01 & 1.00 & & & & & & & & \\
\hline 6 Spin-out size (current) & 12.71 & 66.59 & -0.02 & 0.04 & -0.02 & 0.00 & 0.68 & 1.00 & & & & & & & \\
\hline 7 Spin-out age & 3.80 & 2.56 & -0.06 & 0.02 & -0.13 & 0.01 & 0.03 & 0.06 & 1.00 & & & & & & \\
\hline 8 Spin-out age^2 & 21.02 & 26.65 & -0.06 & 0.02 & -0.14 & 0.01 & 0.03 & 0.05 & 0.96 & 1.00 & & & & & \\
\hline 9 Avg employment of parent firm(s) & 352.9 & 4456.5 & 0.00 & 0.01 & -0.03 & -0.01 & 0.01 & 0.02 & -0.04 & -0.04 & 1.00 & & & & \\
\hline 10 Age of parent firm at spin-out birth & 2.96 & 2.44 & -0.02 & 0.03 & 0.58 & 0.02 & 0.00 & -0.02 & -0.28 & -0.27 & -0.02 & 1.00 & & & \\
\hline 11 D ummy: Age of parent firm is censored & 0.19 & 0.39 & 0.00 & 0.08 & 0.07 & -0.03 & 0.01 & 0.03 & 0.11 & 0.11 & -0.03 & 0.07 & 1.00 & & \\
\hline 12 \# firms in MSA & 2888 & 3551 & -0.10 & 0.01 & 0.07 & 0.06 & -0.02 & -0.03 & 0.18 & 0.19 & 0.06 & 0.16 & -0.15 & 1.00 & \\
\hline 13\# firms in MSA^2 / 1000 & 21000 & 49200 & -0.09 & 0.00 & 0.06 & 0.04 & -0.01 & -0.02 & 0.15 & 0.16 & 0.07 & 0.14 & -0.14 & 0.95 & 1.00 \\
\hline
\end{tabular}

Note: Sample size of all variables is 42,624 firm years spanning approximately 10,000 spin-outs. 
TABLE 3

Influence of Founder quality on Spin-out Team Size and Spin-out Team Tenure (Parent firm sample)

\begin{tabular}{|c|c|c|c|c|}
\hline \multirow[b]{2}{*}{ Variable } & \multicolumn{2}{|c|}{$\begin{array}{c}\text { Model } 1 \\
\mathrm{DV}=\text { Spin-out team size }\end{array}$} & \multicolumn{2}{|c|}{$\begin{array}{c}\text { Model } 2 \\
\mathrm{DV}=\text { Avg tenure, spin-out team }\end{array}$} \\
\hline & Coefficient & Std. Err & Coefficient & Std. Err \\
\hline Founder quality: founder earnings (x1000) & 0.0100 & $(0.0004) * * *$ & 0.0074 & $(0.0005) * * *$ \\
\hline Avg leader earnings, all departing teams (x1000) & -0.0128 & $(0.0008) * * *$ & -0.0088 & $(0.0009) * * *$ \\
\hline Avg team size, all departing teams & 1.2455 & $(0.0305) * * *$ & 0.0827 & $(0.0313) * * *$ \\
\hline Total number of departing employees & -0.0021 & $(0.0002) * * *$ & 0.0002 & $(0.0002)$ \\
\hline Revenue variance (x1000) & -0.0001 & $(0.0002)$ & -0.0001 & $(0.0002)$ \\
\hline Firm age & 0.0455 & $(0.0266) *$ & 0.0175 & $(0.0273)$ \\
\hline \# firms in MSA & -0.0002 & $(0.0002)$ & -0.0003 & $(0.0002)$ \\
\hline \# firms in MSA^2 (x10000) & 0.0002 & $(0.0004)$ & 0.0007 & $(0.0004) *$ \\
\hline Constant & -0.2042 & $(0.9904)$ & 0.4764 & $(1.0164)$ \\
\hline N Observations & 11822 & & 11822 & \\
\hline N Groups & 7349 & & 7349 & \\
\hline R-sq: within = & 0.3674 & & 0.4999 & \\
\hline between $=$ & 0.3994 & & 0.6783 & \\
\hline overall $=$ & 0.3522 & & 0.5956 & \\
\hline
\end{tabular}

Notes: Model includes firm and year fixed effects. Standard errors are robust and clustered on parent firm.

D emographic controls for exiting employees and all employees (avg. age, education, tenure, gender, and race) were not significant and are unreported. *** Significant at the 1\% level ** Significant at the 5\% level * Significant at the 10\% level.

TABLE 4

Influence of Founder quality on Spin-out Team Size and Spin-out Team Tenure (spin-out firm sample)

\begin{tabular}{|c|c|c|c|c|}
\hline \multirow[b]{2}{*}{ Variable } & \multicolumn{2}{|c|}{$\begin{array}{c}\text { Model } 1 \\
\text { DV=Spin-out Team Size }\end{array}$} & \multicolumn{2}{|c|}{$\begin{array}{c}\text { Model 2 } \\
\mathrm{DV}=\text { Avg Tenure, spin-out team }\end{array}$} \\
\hline & Coefficient & Robust Std. Err & Coefficient & Robust Std. Err \\
\hline Founder quality: founder earnings (x1000) & 0.0057 & $(0.0016)^{* * *}$ & 0.0026 & $(0.0007)^{* * *}$ \\
\hline Spin-out total size at birth & 0.0012 & $(0.0004) * * *$ & -0.0004 & $(0.0002) * *$ \\
\hline Spin-out age & 0.0006 & $(0.0130)$ & 0.0912 & $(0.0092) * * *$ \\
\hline Spin-out age 2 & 0.0012 & $(0.0013)$ & -0.0053 & $(0.0006) * * *$ \\
\hline Avg employment of parent firm(s) (x10000) & 0.0559 & $(0.0351)$ & -0.0544 & $(0.0192) * * *$ \\
\hline Age of parent firm at spin-out birth & 0.0199 & $(0.0105) *$ & 0.4507 & $(0.0091) * * *$ \\
\hline Dummy: Age of parent is censored & 0.4322 & $(0.0870) * * *$ & 0.0694 & $(0.0457)$ \\
\hline \# of firms in MSA & $3.5 \mathrm{E}-05$ & $(2.7 \mathrm{E}-05)$ & $-1.5 \mathrm{E}-05$ & $(1.5 \mathrm{E}-05)$ \\
\hline$\#$ of firms in $\mathrm{MSA}^{\wedge} 2(\mathrm{x} 100000)$ & $-2.0 \mathrm{E}-04$ & $(1.5 \mathrm{E}-04)$ & $2.5 \mathrm{E}-06$ & $(8.4 \mathrm{E}-05)$ \\
\hline Constant & 0.9310 & $(0.1284) * * *$ & -0.1269 & $(0.0669) *$ \\
\hline $\begin{array}{l}\text { N Observations } \\
\mathrm{B}^{\wedge} \text { ? }\end{array}$ & 42624 & & 42624 & \\
\hline
\end{tabular}

Note: All models include year fixed effects. Standard errors are robust and clustered on parent firm. The universe represents approximately 10,000 spin-outs. *** Significant at the 1\% level ** Significant at the 5\% level * Significant at the $10 \%$ level. 
TABLE 5

Influence of Founder Q uality on Parent Firm Performance

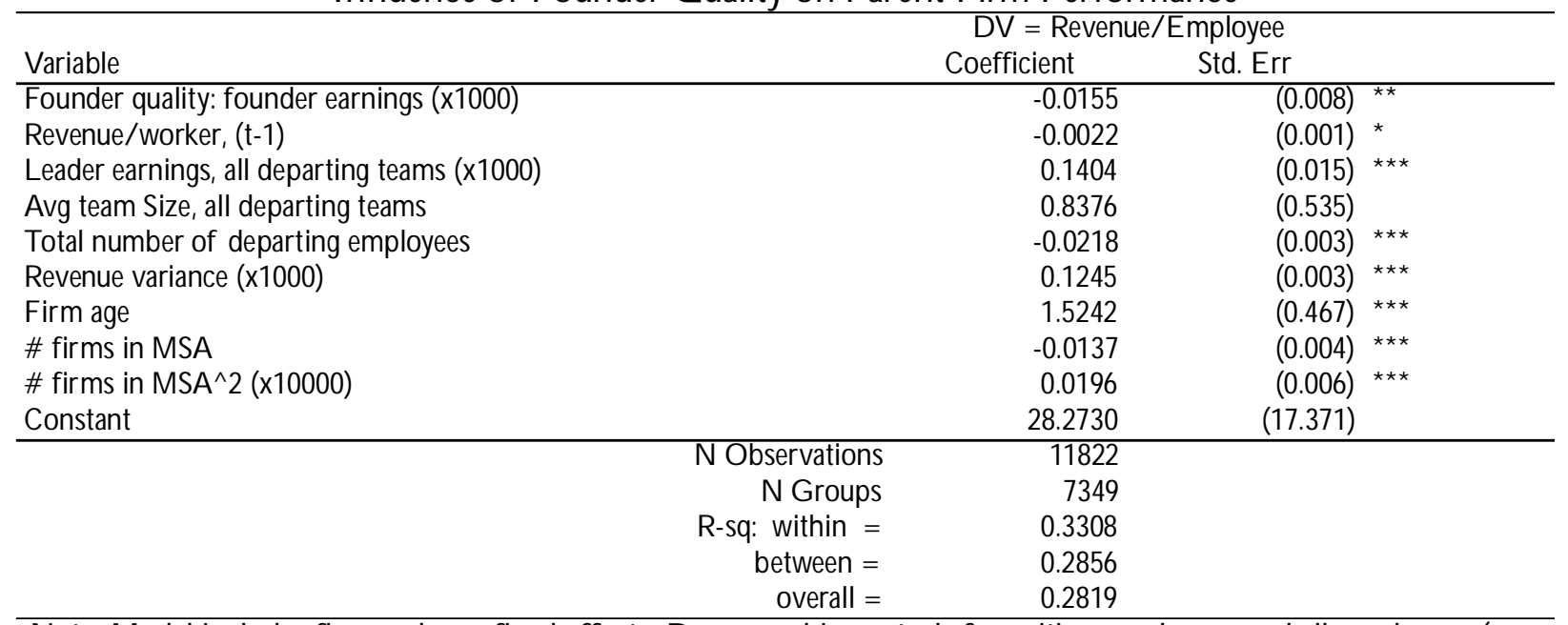

Note: Model includes firm and year fixed effects. Demographic controls for exiting employees and all employees (avg. age, education, tenure, gender, and race) were almost all insignificant and are unreported. ${ }^{* * *}$ Significant at the $1 \%$ level ** Significant at the $5 \%$ level * Significant at the $10 \%$ level.

TABLE 6

Influence of Founder Q uality on Spin-out Performance

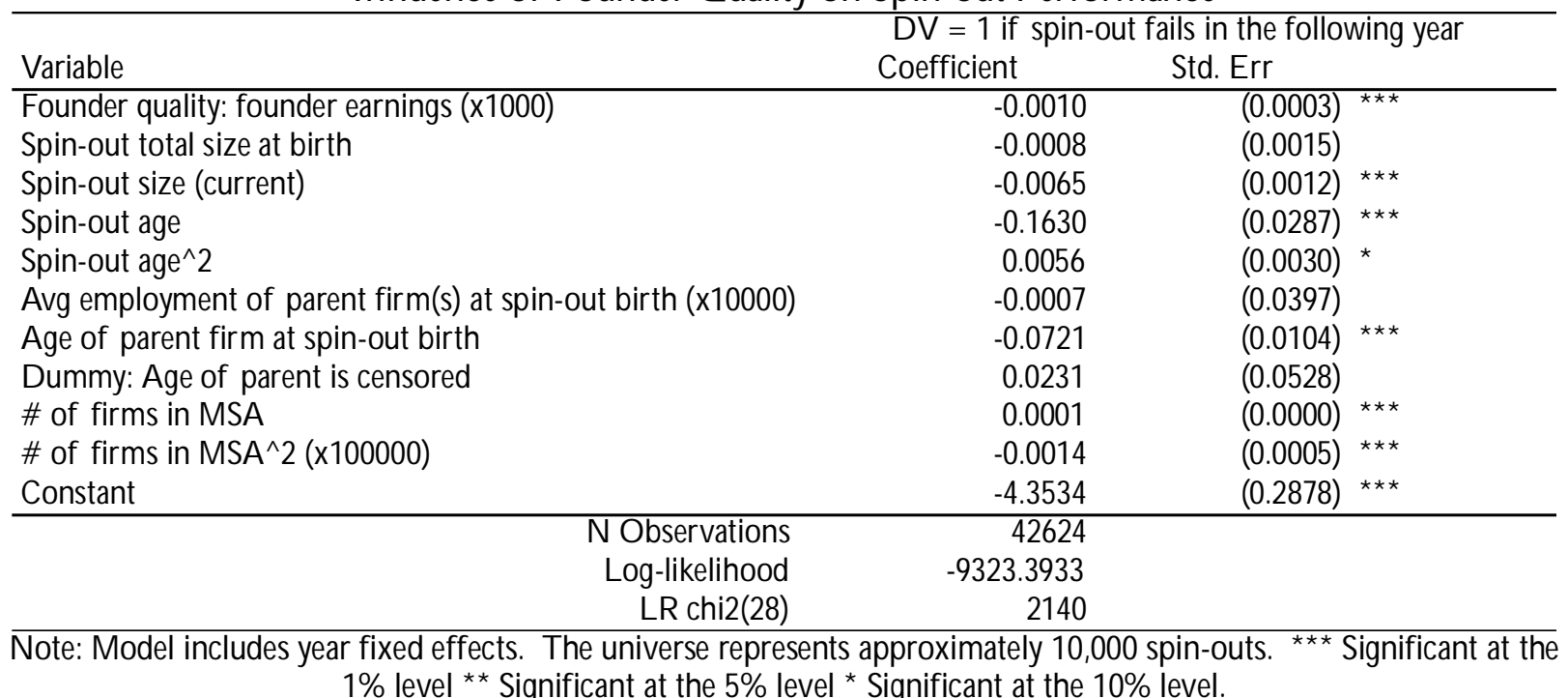

$1 \%$ level $* *$ Significant at the $5 \%$ level * Significant at the $10 \%$ level. 
TABLE 7

Influence of Founder Q uality and Mediators on Parent Firm Performance

\begin{tabular}{|c|c|c|c|c|c|c|c|}
\hline DV = Revenue/ Employee & & & Mo & & & & \\
\hline Variable & Coefficient & Std. Err & Coefficient & Std. Err & Coefficient & Std. Err & \\
\hline Founder quality: founder earnings (x1000) & -0.008 & $(0.008)$ & -0.018 & $(0.008)^{* *}$ & -0.010 & $(0.008)$ & \\
\hline Spin-out team size & -0.692 & $(0.227) * * *$ & & & -0.702 & $(0.227)$ & $* * *$ \\
\hline Avg tenure, spin-out team & & & 0.244 & $(0.256)$ & 0.277 & $(0.256)$ & \\
\hline Revenue/ worker, (t-1) & -0.002 & $(0.001) *$ & -0.002 & $(0.001) *$ & -0.002 & $(0.001)$ & * \\
\hline Leader earnings, all departing teams (x1000) & 0.138 & $(0.015) * * *$ & 0.046 & $(0.015) * * *$ & 0.140 & $(0.015)$ & $* * *$ \\
\hline Avg team size, all departing teams & 0.098 & $(0.028) * * *$ & 0.085 & $(0.027) * * *$ & 0.098 & $(0.028)$ & $* * *$ \\
\hline Total number of departing employees & -0.030 & $(0.004) * * *$ & -0.029 & $(0.004) * * *$ & -0.030 & $(0.004)$ & $* * *$ \\
\hline Revenue variance of parent firm (x1000) & 0.125 & $(0.003) * * *$ & 0.125 & $(0.003) * * *$ & 0.125 & $(0.003)$ & $* * *$ \\
\hline Age of parent firm at spin-out birth & 1.632 & $(0.467) * * *$ & 1.568 & $(0.467) * * *$ & 1.627 & $(0.467)$ & $* * *$ \\
\hline \# firms in MSA & -0.014 & $(0.004) * * *$ & -0.014 & $(0.004) * * *$ & -0.014 & $(0.004)$ & $* * *$ \\
\hline \# firms in MSA^2 (x10000) & 0.020 & $(0.006) * * *$ & 0.020 & $(0.006) * * *$ & 0.020 & $(0.006)$ & $* * *$ \\
\hline Constant & 28.064 & $(17.340)$ & 27.661 & (17.357) & 27.932 & $(17.340)$ & \\
\hline N Observations & 11822 & & 11822 & & 11822 & & \\
\hline N Groups & 7349 & & 7349 & & 7349 & & \\
\hline R-sq: within & 0.3333 & & 0.332 & & 0.3334 & & \\
\hline between & 0.2831 & & 0.2834 & & 0.2832 & & \\
\hline overall & 0.2808 & & 0.2808 & & 0.2809 & & \\
\hline
\end{tabular}

Note: Model includes firm and year fixed effects. D emographic controls for exiting employees and all employees (avg. age, education, tenure, gender, and race) were almost all insignificant and are unreported. *** Significant at the 1\% level ** Significant at the 5\% level * Significant at the $10 \%$ level. 
TABLE 8

Influence of Founder Q uality and Mediators on Spin-out Firm Performance

\begin{tabular}{|c|c|c|c|c|c|c|c|c|c|}
\hline$\overline{D V}=1$ if spin-out fails in the following year & & & & & & & & & \\
\hline Variable & Coefficient & Std. Err & & Coefficient & Std. Err & & Coefficient & Std. Err & \\
\hline Founder quality: founder earnings (x1000) & -0.0006 & $(0.0003)$ & * & -0.0007 & $(0.0003)$ & ** & -0.0003 & $(0.0003)$ & \\
\hline Spin-out team size at birth & -0.0604 & $(0.0154)$ & $* * *$ & & & & -0.0556 & $(0.0152)$ & *** \\
\hline Avg tenure, spin-out team & & & & -0.0672 & $(0.0144)$ & $* * *$ & -0.0629 & $(0.0143)$ & *** \\
\hline Spin-out size (current) & -0.0059 & $(0.0012)$ & $* * *$ & -0.0066 & $(0.0012)$ & $* * *$ & -0.0061 & $(0.0012)$ & *** \\
\hline Spin-out age & -0.1631 & $(0.0287)$ & $* * *$ & -0.1578 & $(0.0287)$ & *** & -0.1582 & $(0.0287)$ & *** \\
\hline Spin-out age ${ }^{\wedge}$ & 0.0056 & $(0.0030)$ & $*$ & 0.0053 & $(0.0030)$ & * & 0.0053 & $(0.0030)$ & * \\
\hline Avg employment of parent firm(s) (x10000) & 0.0017 & $(0.0397)$ & & -0.0027 & $(0.0402)$ & & -0.0006 & $(0.0402)$ & \\
\hline Age of parent firm at spin-out birth & -0.0712 & $(0.0104)$ & $* * *$ & -0.0439 & $(0.0118)$ & $* * *$ & -0.0449 & $(0.0118)$ & *** \\
\hline Dummy: Age of parent is censored & 0.0408 & $(0.0529)$ & & 0.0272 & $(0.0528)$ & & 0.0426 & $(0.0529)$ & \\
\hline \# of firms in MSA & 7.7E-05 & $(3.0 \mathrm{E}-05)$ & ** & $7.8 \mathrm{E}-05$ & $(3.0 \mathrm{E}-05)$ & ** & 7.5E-05 & $(3.0 \mathrm{E}-05)$ & ** \\
\hline \# of firms in MSA^2 (x100000) & $-1.4 \mathrm{E}-03$ & $(4.6 \mathrm{E}-04)$ & $* * *$ & $-1.4 \mathrm{E}-03$ & $(4.6 \mathrm{E}-04)$ & *** & $-1.4 \mathrm{E}-03$ & $(4.6 \mathrm{E}-04)$ & *** \\
\hline Constant & -4.3090 & $(0.2895)$ & $* * *$ & -4.3615 & $(0.2880)$ & $* * *$ & -4.3184 & $(0.2895)$ & *** \\
\hline N Observations & 42624 & & & 42624 & & & 42624 & & \\
\hline Log-likelihood & -9314.2974 & & & -9312.41 & & & -9304.58 & & \\
\hline LR chi2(28) & 2158.19 & & & 2161.95 & & & 2177.62 & & \\
\hline
\end{tabular}

Note: All models include year fixed effects. The universe represents approximately 10,000 spin-outs. *** Significant at the $1 \%$ level ** Significant at the $5 \%$ level * Significant at the $10 \%$ level. 
TABLE 9

Mediation Model Test Statistics

Spin-out performance

\begin{tabular}{|c|c|c|c|c|c|c|c|c|c|}
\hline & $\mathrm{C}$ & $\mathrm{a}$ & SE_a & B & $\mathrm{SE} \_\mathrm{b}$ & $\mathrm{Z}$ & $\begin{array}{l}\text { effect } \\
\text { ratio }\end{array}$ & \multicolumn{2}{|c|}{ MCMAM 95\% CI } \\
\hline Mediator: spin-out team size & -0.001 & 0.0057 & 0.0016 & -0.0604 & 0.0154 & -2.637049 & 0.34428 & -0.00063 & -0.00012 \\
\hline Mediator: spin-out team tenure & -0.001 & 0.0026 & 0.0007 & -0.0672 & 0.0144 & -2.906147 & 0.17472 & -0.00031 & -0.00007 \\
\hline \multicolumn{10}{|l|}{ Parent firm performance } \\
\hline & $\mathrm{C}$ & $\mathrm{a}$ & SE_a & B & $\mathrm{SE} \_\mathrm{b}$ & $\mathrm{Z}$ & $\begin{array}{l}\text { effect } \\
\text { ratio }\end{array}$ & \multicolumn{2}{|c|}{ MCMAM 95\% CI } \\
\hline Mediator: spin-out team size & -0.016 & 0.01 & 0.0004 & -0.692 & 0.227 & -3.026044 & 0.4325 & -0.01147 & -0.00245 \\
\hline Mediator: spin-out team tenure & -0.016 & 0.0074 & 0.0005 & 0.244 & 0.256 & 0.9511546 & -0.11285 & -0.01917 & 0.05509 \\
\hline
\end{tabular}

Notes: $\mathrm{z}=\mathrm{a}^{*} \mathrm{~b} / \operatorname{sqr}\left(\mathrm{a}^{2} \mathrm{SE} \mathrm{b}^{2}+\mathrm{b}^{2} \mathrm{SE} \mathrm{a}^{2}\right)$

effect ratio $=\mathrm{a} * \mathrm{~b} / \mathrm{c}$

MCAM 95\% CI = 95\% confidence interval for the magnitude of the indirect effect using MCMAM with 20,000 repetitions (Selig and Preacher, 2008). 